\title{
PERANAN PERPUSTAKAAN SEKOLAH SEBAGAI SARANA PENDUKUNG GERAKAN LITERASI SEKOLAH DI SEKOLAH MENENGAH PERTAMA
}

\author{
Alexander Kastro \\ Pengawas SMP Dinas Pendidikan Ketapang \\ Email: alexander.kastro@yahoo.co.id
}

\begin{abstract}
Abstrak
Pemerintah dalam hal ini Kementerian Pendidikan dan Kebudayaan telah menggiatkan Gerakan Literasi Nasional (GLN) dan sudah ditetapkan melalui Peraturan Menteri Pendidikan dan Kebudayaan Nomor 23 Tahun 2015 tentang Penumbuhan Budi Pekerti. Bersamaan dengan itu, Direktorat Jendral Pendidikan Dasar dan Menengah mengembangkan Gerakan Litarasi Sekolah untuk meningkatkan daya baca siswa dan menggerakkan literasi bangsa dengan menerbitkan buku pendukung bagi siswa yang berbasis kearifan lokal. Gerakan Literasi Nasional ini telah dilaksanakan secara menyeluruh dan serentak, mulai dari ranah keluarga sampai ke sekolah yang dikenal sebagai Gerakan Literasi Sekolah (GLS). Gerakan Literasi Sekolah sendiri sudah disosialisaikan bersamaan dengan diberlakukannya Kurikulum 13, meskipun tidak semua sekolah sudah melaksanakannya secara maksimal dikarenakan belum didukung oleh sarana prasarana yang memadai. Berbagai sarana yang bisa dimanfaatkan dalam rangka pelaksanaan Gerakan Literasi Sekolah ini, misalnya : sudut baca, taman baca, area ramah anak (peserta didik), dan perpustakaan sekolah. Perpustakaan Sekolah merupakan salah satu sarana fisik dalam menunjang Gerakan Literasi Sekolah. Perpustakaan tidak hanya berkaitan dengan gedung dan buku saja, namun juga sistem penyimpanannya, pemeliharaannya, si pengguna dan bagaimana cara menggunakan dan menfaatkannya.
\end{abstract}

\section{Kata kunci : Gerakan Literasi Sekolah, Sarana Prasarana, Perpustakaan Sekolah}

\section{PENDAHULUAN}

Sejak tahun 2016 Kementerian Pendidikan dan Kebudayaan menggiatkan Gerakan Literasi Nasional sebagai bagian dari implementasi dari Peraturan Pendidikan dan Kebudayaan Nomor 23 Tahun 2015 tentang Penumbuhan Budi Pekerti. Dan ini juga pengintegrasian dari pelaksanaan Kurikulum 13 yang sudah dilaksanakan sejak diberlakukannya peraturan yang terkait dengan perubahan kurikulum yang sudah ditetapkan oleh pemerintah. Pelaksanaan Gerakan Litarasi Nasional yang dilakukan pemerintah melalui Kementerian Pendidikan dan Kebudayaan lebih spesifik diterapkan di sekolah - sekolah mulai dari pendidikan dasar dan menengah sehingga ditetapkan apa yang sekarang lebih dikenal dengan Gerakan Literasi Sekolah (GLS). Gerakan Literasi Sekolah yang ditetapkan oleh pemerintah menjadi Gerakan Literasi Nasional ini merupakan upaya pemerintah untuk mengembangkan budi pekerti siswa agar siswa memiliki budaya membaca dan menulis sehingga tercipta pembelajaran sepanjang hayat . Faktor - faktor lain yang menjadi alasan pemerintah mencanangkan program Gerakan Literasi Sekolah ini adalah; 1).

Adanya fakta hasil survey internasional (PIKS 2011, PISA 2009 dan 2012) yang mengukur bahwa keterampilan membaca dikalangan peserta didik di Indonesia sangat rendah, kita masih kalah dibandingkan dengan negara - negara tetangga kita seperti Singapura dan Malaysia. 2) Melalui gerakan ini pemerintah berharap kegiatan membaca di sekolah perlu dikuatkan lagi dengan pembiasaan membaca di lingkungan keluarga dan masyarakat. 3) Serta nilai - nilai bijak yang terkandung dalam setiap buku/bacaan yang dibaca oleh peserta didik itu sendiri. Diluar daripada berbagai faktor tersebut di atas kendurnya kebiasaan dan minat membaca dikalagan generasi muda dan pelajar berdampak pada perilaku anak - anak kita yang cendrung malas, kurang semangat, tidak kreatif sehingga berakibat menrunnya prestasi belajar di sekolah, dan yang memprihatinkan lagi munculnya berbagai peristiwa dikalangan pelajar sehingga sangat mengkwatirkan para orangtua.

Maka melalui Gerakan Literasi Sekolah inilah pemerintah berharap dengan budaya 
membaca di kalangan generasi muda dapat menumbuh kembangkan keterampilan membaca dan menulis bagi peserta didik yang akan berdampak terhadapperilaku dan budi pekerti anak -anak kita sehingga mampu menekan perbuatan - perbuatan yang merusak moralitas generasi penerus kita di masa yang akan datang. Terkait dengan direncanankannya Gerakan Literasi Sekolah, maka hal penting yang perlu dilakukan oleh sekolah adalah membangun lingkungan fisik sekolah yang kaya literasi, antara lain : a) Menyediakan Perpustakaan Sekolah, sudut baca, taman baca, dan area - area ramah anak yang menyenangkan; b) Pengembangan sarana penunjang lain seperti UKS, kantin sekolah, kebun sekolah, dan lain sebagainya. Perpustakaan Sekolah yang merupakan salah satu sarana fisik dalam menunjang Gerakan Literasi Sekolah menjadi tempat yang sangat penting bagi peserta didik di sekolah untuk melakukan kegiatan membaca. Perpustakaan sekolah tidak hanya berkaitan dengan gedung dan buku saja, namun juga sistem penyimpanan, pemeliharaan, pengguna dan bagaimana cara menggunakan atau memanfaakannya. Maka perpustakaan sekolah dapat kita artikan sebagai kesatuan unit kerja yang terdiri dari beberapa bagian yaitu bagian pengembangan koleksi, pengelohan koleksi, bagian layanan pengguna dan bagian pemeliharaan sarana prasarana.

Fungsi utama perpustakaan sekolah menengah adalah membantu tercapainya tujuan sekolah menengah, yaitu antara lain agar anak anak tamatan sekolah menengah memiliki ilmu pengetahuan yang kukuh dan terampil penggunaannya untuk melanjutkan pendidikan ke sekolah menengah lanjutan. Perpustakaan sekolah bertujuan menyerap dan menghimpun informasi, sebagai media pengetahuan yang terorganisasi, menumbuhkan kemampuan menikmati pengalaman imajinatif, membantu perkembangan kecakapan bahasa dan daya pikir, mendidik murid agar dapat menggunakan dan memelihara bahan pustaka secara efisien serta memberikan dasar ke arah studi mandiri. Dari penjelasan yang telah diuraikan di atas, maka terdapat keterkaitan antara perpustakaan dengan gerakan literasi sekolah sehingga menunjukan bahwa pentingnya mengetahui bagaimana peranan perpustakaan dalam menunjang penerapan gerakan literasi sekolah. Adapun tujuan penelitian ini ialah ntuk mendeskripsikan bentuk pelaksanaan gerakan literasi sekolah di Sekolah Menegah Petama (SMP).Untuk mendeskripsikan kegiatan peranan perpustakaan dalam menunjang penerapan gerakan literasi sekolah di Sekolah Menegah Petama (SMP).

Perpustakaan sekolah sebagai salah satu sarana pendidikan penunjang kegiatan belajar siswa memegang peranan yang sangat penting dalam memacu tercapainya tujuan pendidikan di sekolah. Dalam Undang - Undang Sistem Pendidikan Nasional (UU No.2 Tahun 1989), sarana penunjang proses kegiatan belajar mengajar dinamakan "sumber daya pendidikan". Pada pasal 35 disebutkan bahwa "setiap satuan pendidikan jalur pendidikan sekolah yang diselenggarakan oleh pemerintah maupun masyarakat harus meyediakan sumber belajar". Pada penjelasan selanjutnya dinyatakan antara lain : "Pendidikan tidak mungkin terselenggara dengan baik bila para tenaga kependidikan maupun siswa tidak didukung oleh sumber belajar yang diperlukan untuk penyelenggaran kegiatan kegiatan belajar mengajar yang bersangkutan. Annisa, 2017 mengemukakan bahwa perpustakaan dapat pula disartikan sebagai tempat kumpulan buku atau tempat buku dihimpun dan diorganisasikan sebagai media belajar siswa.

Perpustakaan sekolah adalah perpustakaan yang ada di lingkungan sekolah, maka secara umum perpustakaan sekolah adalah suatu unit kegiatan yang berada dilingkungan sekolah yang dikelola secara profesional untuk memberikan informasi kepada penggunanya. Melalui perpustakaan sekolah siswa dapat mendidik dirinya secara berkesinambungan, dan dapat menumbuhkan minat baca. Annisa, 2017 menyatakan bahwa perpustakaan sekolah sangat diperlukan keberadaanya dengan pertimbangan bahwa : a) Perpustakaan sekolah merupakan sumber belajar di lingkungan sekolah, b) Perpustakaan sekolah merupakan salah satu komponen sistem pengajaran, c) Perpustakaan sekolah merupakan sumber untuk menunjang kualitas pendidikan dan pengajaran, d) Perpustakaan sekolah sebagai laboratorium belajar yang memungkinkan siswa dapat mempertajam dan memperluas kemampuan untuk membaca, menulis, berpikir dan berkomunikasi. Menurut beberapa para ahli diatas dapat ditarik sebuah kesimpulan bahwa perpustakaan sekolah adalah perpustakaan yang berada di lingkungan sekolah Perpustakaan sekolah merupakan pusat terkumpulnya berbagai bahan pustaka untuk menambah wawasan, informasi, dan untuk mendukung berlangsungnya kegiatan belajar mengajar sesuai dengan tujuan pendidikan. 
Setiap perpustakaan sekolah pasti memiliki tujuan yang mendukung terselenggaranya proses belajar mengajar. Menurut Soeatminah, 1992 menyatakan bahwa tujuan didirikannya perpustakaan sekolah tidak terlepas dari tujuan diselenggarakannya pendidikan sekolah yaitu untuk memberikan bekal kemampuan dasar kepada siswa, dan mempersiapkan mereka untuk menglikuti pendidikan menengah atas. Sejalan dengan hal tersebut di atas, maka tujuan perpustakaan sekolah yaitu : a) Mendorong proses penguasaan teknik membaca, b) Membantu menulis kreatif, c) Menumbuhkembangkan minat dan kebiasaan membaca, d) Menyediakan berbagai macam sumber informasi, e) Mendorong minat baca, f) Memperkaya pengalaman dengan membaca buku yang disediakan oleh perpustkaan , g) Mengisi waktu sengggang melalui kegiatan membaca. Perpustakaan sekolah sebagai salah satu sumber belajar yang dibutuhkan oleh siswa dan guru di sekolah dalam kegiatan belajar mengajar. Setiap perpustakaan sekolah memilki berbagai manfaat bagi siswa maupun guru dalam melaksanakan kegiatan belajar mengajar di kelas. Secara terinci, manfaat perpustakaan sekolah yang baik yang di selenggarakan di sekolah dasar maupun di sekolah menengah, seperti yang duinyatakan Bafadal (2001 :5) adalah sebagai berikut : (a) Perpustakaan sekolah dapat menimbulkan kecintaan siswa terhadap membaca; (b) Perpustakaan sekolah dapat memperkaya pengalaman belajar siswa; (c) Perpustakaan sekolah dapat melatih siswa ke arah tanggung jawab, (d) Perpustakaan sekolah dapat mempercepat proses penguasaan teknik membaca, (e) Perpustakaan memperlancar siswa dalam meyelesaikan tugas sekolah, dan (f) Perpustakaan sekolah dapat menenamkan kebiasaan belajar mandiri, dan (g) Perpustakaan sekolah dapat membantu guru menemjkan sumber pengajaran.

Berdasarkan pendapat diatas dapat disimpulkan bahwa manfaat perpustakaan secara umum yaitu menanamkan budaya baca dalam menumbuhkan minat baca pada siswa. Beberapa manfaat perpustakaan sekolah tersebut akan berjalan dengan sesuai yang diharapkan oleh sekolah, maka siswa, guru, pustakawan mendukung dan menggunakan perpustakaan sebagai sumber belajar di sekolah.

Perpustakaan sekolah sebagai tempat menyimpan koleksi bahan pustaka yang diatur secara sistematis oleh pustakawan serta digunakan untuk sumber informasi. Soeatminah, 1992 Mengemukakan bahwa perpustakaan mengemban beberapa fungsi umum yaitu : a) fungsi informasi; b) fungsi pendidikan, c) fungsi penelitian, dan d) fungsi rekreasi. Perpustakaan menyediakan berbagai informasi yang meliputi bahan cetak, terekam, maupun koleksi lainnya agar pengguna perpustakaan dapat mengambil berbagai idedari buku yang ditulis oleh para ahli dari berbagai bidang ilmu . Pengunjung perpustakaan sekolah memilki kesempatan untuk mendapatkan berbagai informasi yang tersedia di perpustakaan untuk memecahkan masalah yang dihadapi dalam kehidupan sehari - hari di masyarakat.

Perpustakaan sekolah merupakan salah satu dari berbagai macam sumber belajar yang tersedia di lingkungan sekolah. Mengacu pada definisi sumber belajar yang diberikan oleh Association for Education Communication Technology megemukakan pengertian sumber belajar adalah berbagai sumber, baik itu berupa data orang atau wujud tertentu yang dapat digunakan oleh siswa dalam belajar baik yang digunakan secara terpisah maupun secara terkombinasi sehingga mempermudah siswa dalam mencapai tujuan belajarnya. Ditinjau dari segi pendayagunaan, Association for Education Communication Technology (AECT) membedakan sumber belajar menjadi dua macam yaitu : Pertama, sumber belajar yang dirancang untuk digunakan dalam kegiatan belajar. Sumber belajar yang dirancang tersebut dapat berupa buku teks, buku paket, slide, film, video. Sedangkan Kedua, yaitu sumber belajar yand tidak dirancang dan jenis ini banyak terdapat disekitar kita. Contoh sumber belajar jenis ini adalah tokoh masyarakat, toko, pasar, dan meseum. Berdasarkan pendapat para ahli diatas dapat disimpulkan bahwa perpustakaan sekolah dapat digunakan sebagai sumber belajar dan informasi oleh guru dan siswa di sekolah. Oleh karena itu, perpustakaan merupakan salah satu sarana yang dibutuhkan oleh sekolah guna membantu upaya pembelajaran berjalan sesuai dengan tujuan sekolah.

Secara umum perpustakaan sekolah sangat dibutuhkan di lingkungan sekolah sebagai penunjang keberhasilan proses belajar mengajar. Perpustakaan sekolah juga sangat dipengaruhi oleh jenjang sekolah. Dibandingkan perpustakaan sekolah di jenjang pendidikan Dasar (SD), perpustakaan sekolah di Sekolah Menengah Pertama lebih memadai. Secara umum Sekolah Menengah Pertama sudah memiliki gedung perpustakaan namun tidak semua sekolah dapat mengelola perpustakaan di sekolah dengan baik. Ada sekolah yang sudah baik dalam mengelola 
perpustakaannya baik secara administrasi, luas sesuai ketentuan, sarana buku, perabot, media pendidikan, tata letak bangunan, ruang sirkulasi, dan sebagainya. Di lain pihak masih banyak juga sekolah yang belum maksimal dalam pengelolaan perpustakaan sekolah; bahkan banyak yang belum memilki ruang perpustakaan, tidak memilki ruang baca, jam buka belum teratur dan tidak memungkinkan siswa menggali sendiri kebutuhan informasi yang dibutuhkan di perpustakaan sekolah, serta petugas belum jelas apakah dia seorang guru kelas, tenaga administrasi atau pustakawan.

Membaca merupakan suatu kegiatan atau proses kognitif yang berupaya untuk menemukan berbagai informasi yang terdapat dalam tulisan (Dalman, 2013: 5). Membaca merupakan merupakan keterampilan berbahasa dan faktor yang penting dalam proses pembelajaran, karena dengan membaca peserta didik dapat memperoleh informasi. Membaca merupakan salah satu kegiatan dalam berliterasi. Literasi tidak dapat dipisahkan dari dunia pendidikan. Literasi menjadi sarana peserta didik dalam mengenal, memahami, dan menerapkan ilmu yang didapatkannya di bangku sekolah. Far (1984: 5) mengemukakan, "reading is the heart of education" yang artinya membaca merupakan jantung pendidikan. Dalam hal ini, orang yang sering membaca, pendidikannya akan maju dan ia akan memiliki wawasan yang luas. Tentu saja hasil membacanya itu akan menjadi skemata baginya. Skemata ini adalah adalah pengetahuan dan pengalaman yang dimiliki seseorang. Jadi, semakin sering seseorang membaca, maka semakin besarlah peluang mendapatkan skemata dan berarti semakin maju pulalah pendidikannya. Hal inilah yang melatarbelakangi banyak orang yang mengatakan bahwa membaca sama dengan membuka jendela dunia. Gerakan Literasi Sekolah merupakan merupakan suatu usaha atau kegiatan yang bersifat partisipatif dengan melibatkan warga sekolah (peserta didik, guru, kepala sekolah, tenaga kependidikan, pengawas sekolah, Komite Sekolah, orang tua/ wali murid peserta didik), akademisi, penerbit, media massa, masyarakat (tokoh masyarakat yang dapat merepresentasikan keteladanan, dunia usaha, dll.), dan pemangku kepentingan di bawah koordinasi Direktorat Jenderal Pendidikan

Dasar dan Menengah Kementerian Pendidikan dan Kebudayaan. Secara teknis mengembangkan suatu kebijakan di suatu sekolah yang "sehat" bukanlah suatu hal yang terlampau sukar. Ide tentang gerkan literasi sekolah seperti ini merupakan suatu ide yang sudah diketahui oleh tenaga-tenaga pendidik. Pertumbuhan suatu kebijakan seperti gerakan literasi sekolah tentu saja memerlukan waktu. Kebijakan semacam ini tidak dapat ditegakkan dalam waktu satu bulan atau satu tahun. Karena proses transformasi sekolah itu sendiri juga merupakan suatu proses yang membutuhkan waktu (Buchori, 1995 :164). Gerakan Literasi Sekolah adalah gerakan sosial dengan dukungan kolaboratif berbagai elemen. Upaya yang ditempuh untuk mewujudkannya berupa pembiasaan membaca peserta didik. Pembiasaan ini dilakukan dengan kegiatan 15 menit membaca (guru membacakan buku dan warga sekolah membaca dalam hati, yang disesuaikan dengan konteks atau target sekolah). Ketika pembiasaan membaca terbentuk, selanjutnya akan diarahkan ke tahap pengembangan, dan pembelajaran.

Variasi kegiatan dapat berupa perpaduan pengembangan keterampilan reseptif maupun produktif. Gerakan Literasi Sekolah mempunyai dua tujuan, yaitu tujuan umum dan tujuan khusus. Tujuan Umum Gerakan Literasi Sekolah, yaitu menumbuhkembangkan budi pekerti peserta didik melalui pembudayaan ekosistem literasi sekolah yang diwujudkan dalam Gerakan Literasi Sekolah agar mereka menjadi pembelajar sepanjang hayat. Sedangkan tujuan khusus Gerakan Literasi Sekolah, yaitu : (1) menumbuhkembangkan budaya literasi di sekolah; (2) meningkatkan kapasitas warga dan lingkungan sekolah agar literat; (3) menjadikan sekolah sebagai taman belajar yang menyenangkan dan ramah anak agar warga sekolah mampu mengelola pengetahuan; (4) menjaga keberlanjutan pembelajaran dengan menghadirkan beragam buku bacaan dan mewadahi berbagai strategi membaca (Dirjen Dikdasmen, 2016: 1).

Kemudian prinsip-prinsip kegiatan membaca di dalam tahap pembiasaan, yaitu: (1) guru menetapkan waktu 15 menit membaca setiap hari. Sekolah bisa memilih menjadwalkan waktu membaca di awal, tengah, atau akhir pelajaran, bergantung pada jadwal dan kondisi sekolah masing-masing. Kegiatan membaca dalam waktu pendek, namun sering dan berkala lebih efektif daripada satu waktu yang panjang namun jarang (misalnya $1 \mathrm{jam} /$ minggu pada hari tertentu); (1) buku yang dibaca/ dibacakan adalah buku nonpelajaran; (3) peserta didik dapat diminta membawa bukunya sendiri dari rumah; (4) buku yang dibaca/ dibacakan adalah pilihan peserta didik sesuai minat dan kesenangannya; (5) 
kegiatan membaca/membacakan buku di tahap ini tidak diikuti oleh tugas-tugas yang bersifat tagihan/ penilaian; (6) kegiatan membaca/ membacakan buku di tahap ini dapat diikuti oleh diskusi informal tentang buku yang dibaca/ dibacakan, meskipun begitu tanggapan peserta didik bersifat opsional dan tidak dinilai; (7) Kegiatan membaca/ membacakan buku di tahap ini berlangsung dalam suasana yang santai, tenang, dan menyenangkan. Suasana ini dapat dibangun melalui pengaturan tempat duduk, pencahayaan yang cukup terang dan nyaman untuk membaca, poster-poster tentang pentingnya membaca; (8) dalam kegiatan membaca dalam hati, guru sebagai pendidik juga ikut membaca buku selama 15 menit (Dirjen Dikdasmen, 2016: 8).

GLS merupakan salah satu upaya nyata membangun insan dalam ekosistem pendidikan dan kebudayaan yang andal. GLS mendorong terciptanya lingkungan sekolah yang literat dengan ciri menyenangkan dan ramah anak sehingga menumbuhkan semangat warganya dalam belajar; semua warganya menunjukkan empati, peduli, dan menghargai sesama; menumbuhkan semangat ingin tahu dan cinta pengetahuan, memampukan warganya cakap berkomunikasi dan dapat berkontribusi pada lingkungan sosialnya, mengakomodasi partisipasi seluruh warga dan lingkungan eksternal (Kemdikbud, 2016).

Agar pelayanan sirkulasi dan pelayanan referensi berjalan dengan lancar dan teratur perlu dibuat peraturan berupa tata tertib yang baik oleh pengunjung maupun oleh petugas perpustakaan sekolah. Tata tertib ini sebaiknya dibuat oleh Panitia khusus yang melibatkan kepala sekolah, guru - guru, panitia perpustakaan dan segenap petugas perpustakaan sekolah. Tata tertib ini harus dibuat secara singkat, jelas dan sederhana sehingga mudah dimengerti oleh semua pengunjung. Masalah - masalah yang harus dicantumkan dalam tata tertib meliputi : (1) Sifat dan status perpustakaan sekolah; (2) Keanggotaan perpustakaan sekolah; (3) Bahan - bahan pustaka yang tersedia; (4) Sanksi dan hukuman bagi pelajar; (5) Iuran bagi setiap anggota; (6) Sistem penyelenggaran; (7) Waktu pelayanan atau jam buka

Pada setiap tata tertib perpustakaan sekolah dicantumkan sanksi - sanksi tertentu bagi pengunjung yang melanggar larangan - larangan atau melakukan sesuatu yang tidak diperbolehkan, antara lain sebagai berikut Merokok, makan, minum diruang perpustakaan,
Membuata gaduh, berbicara keras, menyanyi, tertawa, bersiul dan bersenda gurau di dalam ruang perpustkaan. Merusak bahan - bahan pustaka dan perlengkapan perpustakaan. Mencorat - coret bahan - bahan pustaka, meja kursi dan perlengkapan lainnya. Memudahkan letak buku sehingga tidak sesuai dengan sistem penempatan yang berlaku. Membawa keluar buku - buku dari perustakaan yang sebelumnya tanpa diproses secara administratif. Membuang sampah disembarang tempat. Terlambat mengembalikan buku - buku yang dipinjamnya.

Pengunjung perpustakaan sekolah yang melanggar larangan - larangan tersebut di atas harus diberi sanksi - sanksi atau hukuman tertentu yang bersifat mendidik, misalnya dengan memberikan denda kepada siswa yang bersangkutan, bagi yang merusak bahan - bahan pustaka harus memperbaiki, pengunjung yang menghilangkan buku - buku yang dipinjam diharuskan mengganti kembali dengan judul buku yang sama. Supaya aturan yang dibuat berjalan dengan tertib maka sanksi - sanksi tersebut harus benar - benar dilakukan dan diterapkan tampa memnadang siapa pelanggarnya.

Pelayanan peminjaman adalah kegiatan kerja yang berupa pemberian bantuan kepada pemakai perpustakaan dalam proses peminjaman dan pengembalian pustaka. Kegiatan kerja ini sering disebut dengan istilah "sirkulasi". Sirkulasi mengandung maksud mengedarkan koleksi perpustakaan kepada pemakainya. Pustakawan harus pandai menentukan kebijakan dalam mengatur pelayanan yang disesuaikan dengan situasi dan kondisi perpustakaan antara lain, Ruang perpustakaan kecil dan jumlah koleksi sangat terbatas namun merupakan sumber informasi mutakhir. Situasi ini dapat diatasi dengan membuat persyaratan peminjaman yang dapat menjamin pustaka. Terbatasnya jumlah tenaga perpustakaan. Situasi ini dapat diatasi dengan waktu pelayanan, misalnya tidak setiap hari seahri hanya beberapa jam (tidak selama jam kerja).

Sistem layanan untuk melayani peminjaman buku dapat di pilih sistem yaitu sistem terbuka ruangan yang luas jarak antara rak yang satu dengan rak yang lainnya harus luas sehingga pengunjung dapat bergerak untuk melihat koleksi buku. Rak buku tidak boleh terlalu tinggi agar pengunjung tidak kesulitan dalam mengambil buku. Tata letak rak buku juga di atur sehingga pengawas mudah mengawasi pengunjung tampa harus mengganggunya. Pengaturan dan penataan buku harus sesuai dengan petunjuk katalog. 
Rambu - rambu harus ringkas dan jelas dan di pasang pada tempat yang tepat sehingga pengembalian buku diletakkan di tempat yang benar. Ketenangan dan kebersihan ruangan yang memuat banyak orang biasanya menjadi gaduh dan kotor, maka perlu dipersiapkan kiatnya agar ketenangan aman dan kebersihan terjaga. Sistem Tertutup dalam sistem tertutup memerlukan ruangan yang terpisah karena pengujung tidak boleh masuk ke ruang koleksi maka harus ada ruang pemisah antara ruang koleksi dan ruangan yang dapat dimasuki pengunjung. Ruangan pemisahnya bisa menggunakan almari atau menempatkan rak - rak dengan jarak sempit dan tinggi dan hanya petugas yang bisa mengambilnya misalnya dengan menggunakan tangga. Katalog yang digunakan harus lengkap sehingga dapat digunakan untuk menelusuri koleksi buku - buku, baik nama pengarang, judul, maupun subjek isi buku. Tata tertib peminjaman adalah kumpulan peraturan untuk menjaga ketertiban peminjaman dan pengambilan bukuyang diedarkan / sirkulasi.

Dalam tata tertib ditentukan hari dan buka jam perpustakaan apabila jumlah tenaga terbatas, pelayanan tidak harus sama dengan lama jam pegawai, jam kerja $3 / 5$ jam seminggu, tidak seluruhnya diperuntukkan memberikan layanan. Pelayanan perpustakaan tidak harus setiap hari, boleh 5-3 hari saja dalam seminggu. Jamnya pun harus dari 07.00 - 14.00. Setiap perustakaan berhak menentukan siapa yang yang boleh dan berhak menggunakan perpustakaan, baik untuk berkunjungan, mmembaca maupun meminjam perpustakaan. Ada syarat tertentu yang harus dipenuhi oleh calon anggota dicantumkan dalam tata tertib.

Dalam tata tertib harus disebutkan jumlah buku yang boleh dipinjamkan dalam batas waktu tertentu oleh si peminjam buku yang dipinjamkan merupakan hasil perkiraan dan perbandingan jumlah koleksi dengan peminjaman. Dalam tata tertib juga harus disebutkan lama waktu peminjaman. Ketentuan misalnya satu minggu, satu / dua bulan. Semua itu juga dasar perkiraan jangan sampai semua buku koleksi habis dipinjamkan. Dalam menetapkan sanksi bagi pelanggar dapat berupa denda uang, skorsing tidak boleh pinjam buku, mengganti buku yang dipinjam hilang, membersihkan ruang perpustakaan sekolah, dll.

Tata Tertib dan Ketentuan Perpustakaan Sekolah masuk ke ruang perpustakaan dengan tertib, tidak saling berebutan dan mengisi buku kunjungan perpustakaan yang sudah disiapkan oleh pengelola perpustakaan. Dilarang membuat kegaduhan selama berada di dalam ruang peprustakaan; berbicara terlalu keras, bernyanyi, bergurau, atau membunyikan alat - alat yang dapat menimbulkan keributan. Pengunjung perpustakaan diwajibkan menitip barang - barang seperti tas, jaket, dan barang - barang berharga lain pada tempat yang sudah disediakan. Memelihara kebersihan ruang perpustakaan; tidak mencoret meja, dinding maupun fasilitas yang ada di dalam perpustkaan, serta menjaga keutuhan koleksi perpustakaan baik yang dibaca di dalam ruangan maupun di luar perpustakaan; merobek, mengambil koleksi buku yang ada, mencoret - coret buku koleksi, dan lain sebagainya. Pengunjung selalu menjaga kebersihan lingkungan perpustakaan dan sekitarnya; membuang sampah pada tempatnya, tidak meninggalkan sisa makanan, meludah di sembarang tempat, atau merusak tanaman tanaman penghijauan di sekitar perpustakaan. Meletakkan buku - buku yang sudah digunakan di atas meja tempat pengunjung membaca atau sekedar membantu petugas perpustakaan pengunjujg boleh menyusun buku - buku yang sudah digunakan pada rak/tempat yang semula.

Ketentuan Peminjaman Koleksi membawa kartu perpustakaan . Peminjaman hanya boleh dilakukan bagi siswa yang memiliki kartu perpustakaan; tidak bisa dipakaikan kepada siswa yang lain. Jumlah peminjaman maksimal 3 buah buku atau disesuaikan dengan jumlah koleksi buku yang ada disetiap perpustakaan sekolah. Lama peminjaman maksimal selama 5 hari atau disesuaikan dengan kondisi keberadaan perpustakaan sekolah masing -masing. Keterlambatan pengembalian buku akan mendapatkan sanksi dari pengelolaa perustakaan, jadi upayakan mengembalikan buku yang sudah digunakn tepat pada waktunya. Buku - buku yang sudah dikembalikan dipastikan dalam keadaan utuh, bersih, tidak cacat, dan lengkap.

Salah satu kegiatan yang dapat dikelompokkan ke dalam pelayanan teknis adalah pengaturan buku - buku perpustkaan sekolahdengan sebaik mungkin sehingga memudahkan pengambilan dan pengembaliannya. Beberapa hal yang perlu diperhatikan dalam pengelolaan sebuah perpustakaan sekolah adalah Persiapan sebelum perpustakaan sekolah disusun dan disimpan, sebaiknya buku - buku tersebut dilengkapi dengan perlengkapan buku. Semuanya ini nantinya akan mempermudah pelayanan sirkulasi atau peminjaman kepada murid - murid. 
Perlengkapan buku yang dimaksud antara lain berupa label buku, kartu buku peserta kantongnya dan slip tanggal peminjaman. Label buku (call number) merupakan nomor penempatan buku klasifikasi tiga huruf pertama nama keluarga utama, satu huruf pertama judul buku. Label buku ini biasanya ditempelkan pada punggung buku bagian bawah. Kartu buku dapat dibuat dari kertas manila atau kertas gambar yang tebal yang berukuran $7 \times 12 \mathrm{~cm}$. Pada bagian atas buku ini diberi keterangan tentang nomor klasifikasi, judul buku, dan pengarangnya. Kartu buku ini dibagi menjadi dua kolom, kolom pertama untuk mencatat tanggal pengembalian, sedangkan kolom kedua untuk mencatat nomor peminjaman. Nantinya kartu ini dimasukan ke dalam kantong buku. Kantong buku dapat dibuat dari kertas biasa yang berukuran $9 \times 12 \mathrm{~cm}$. Pada kantong buku ini juga dituliskan nomor klasifikasi, judul buku dan pengarangnya. Kantong buku ini ditempelkan pada bagian dalam kulit belakang. Selain dilengkapi dengan kartu buku, sebaiknya setiap buku dilengkapi dengan selembar kertas yang dinamakan slip tanggal atau "date slip". Kegunaannya adalah untuk membubuhkan tanggal harus dikembalikannya buku, agar dapat mengingatkan si pememinjam sewaktu - waktu, slip tanggal ini dapat dibuat dari kertas biasa yang berukuran $7,5 \times 12,5 \mathrm{~cm}$. Slip tanggal ini ditempelkan pada buku yang paling belakang. Usahakan penempelan slip tanggal ini tidak mengganggu teks, indeks dan sebagainya.

Penyusunan buku - buku penyusunan bukubuku perpustakaan sekolah merupakan kegiatan yang tidak kalah pentingnya dengan kegiatan kegiatan lain dalam rangkaian pengelolaan perpustakaan sekolah dan harus mendapatkan perhatian dari pengelola perputakaan sekolah atau pustakawan. Penyusunan buku - buku harus sistematis. Penyusunannya pertama - tama menurut urutan nomor klasifikasi mulai dari nomor terkecil sampai dengan nomor terbesar, kemudian menurut urutan alfabetis dari tiga huruf kependekan nama keluarga/utama pengarang buku dan akhirnya menurut urutan alfabetis dari huruf pertama judul buku. Buku - buku perpustakaan sekolah sebaiknya disusun dan ditempatkan dirak atau lemari buku. Jumlah rak atau lemari buku yang dibutuhkan tentunya sesuai dengan keadaan jumlah buku yang telah dimiliki perpustakaan di sekolah. Untuk mempermudah pencarian buku, setiap rak atau lemari buku yang hanya berisi satu golongan subjek diberi kartu petunjuk atau "guide card" yang bertuliskan angka golongannya, misalnya untuk rak atau lemari buku - buku golongan sosial diberi angka 700, untuk rak lemari buku - bukugolongan ilmu sosial diberi tulisan angka 300, untuk rak atau lemari buku - buku golongan kesusastraan diberi tulisan angka 800, dan seterusnya.

Perawatan buku perpustakaan sekolah buku adalah gudang pengetahuan yang tak pernah ada habisnya. Hargai sumber pengetahuan seluruh warga sekolah dengan memperlakukannya dengan baik. Beberapa tips merawat buku - buku perpustakaan sekolah cara yang termudah adalah merawat daripada mengobati. Biasakan untuk memberi sampul plastik pada buku yang baru saja dibeli. Jangan sekali - kali menggunakan buku sebagai bantal tidur atau pengganjal pintu. Buku tidak boleh dilipat untuk menandai halamannya tapi cukup dengan menyelipkan kertas pembatas buku pada halaman yang belum selesai dibaca. Posisi terbaik untuk meletakkan buku adalah dalam keadaaan beridiri pada rak khusus. Tapi akan lebih baik meyimpannya dalam lemari tertutup atau lemari kaca untuk menghindari debu yang berlebihan. Jangan menjejal - jejalkan rak buku. Berilah sedikit ruang untuk mempermudah pengambilan dan pengaturan buku. Hindarkan buku dari air, minyak, debu dan panas matahari langsung atau lampu berkekuatan tinggi, karena hal tersebut dapat merusak buku. Kertasnya akan cepat berjamur, warnanya menguning dan gampang robek.

Mengatasi kerusakan buku perpustakaan sekolah ada banyak faktor penyebab kerusakan buku, maka cara mengatasinya harus disesuaikan dengan faktor penyebab kerusakan tersebut seperti kelembaban udara, sinar matahari langsung, hewan serangga dan manusia. Syarat Syarat Perpustakaan Sekolah Yang Baik Menurut Wahyu Murtiningsih, secara garis besar faktor faktor yang menjadi sebuah perpustakaan sekolah yang ideal adalah :Sumber daya manusia yang mengelola perpustakaan sekolah. Hal yang terpenting dalam pengadaan SDM menuju perpustakaan yang ideal adalah pustakawan yang berdedikasi tinggi pada tugas dan mempunyai kemampuan plus: (1) Memiliki koleksi yang lengkap. Minimal ketika si pengguna memerlukan pustaka yang diperlukan tersedia; (2) Bangunan perpustakaan secara fisik sesuai dengan ketentuan yang sudah ditetentukan oleh pemerintah. Sudah memenuhi standar; (3) Penataan ruang perpustakaan sekolah disesuaikan dengan tingkat pengguna (siswa sekolah menengah pertama) sehingga membuat mereka betah di dalam ruang perpustakaan sekolah; (4) Letak perpustakaan tidak terlalu dekat dengan 
tempat bermain peserta didik ketika beristirahat, karena perpustakaan merupakan tempat atau ruang untuk membaca yang memerlukan ketenangan sehingga para pengguna perpustakaan sekolah lebih fokus dan terkosentrasi dengan bahan bacaan yang dibacanya; (5) Perpustakaan sekolah perlu menyediakan papan pengumumanuntuk hal - hal yang sifatnya himbauan kepada siswa dan menepel slogan yang bisa memberikan motivasi kepada siswa berhubungan dengan kegiatan membaca.

Dalam rangka menumbuhkembangkan kegemaran membaca dikalangan peserta didik di Sekolah Menengah Pertama (SMP), maka perpustakaan sekolah merupakan salah satu fasilitas pendukung yang sangat dibutuhkan. Dan untuk mendukung program pemerintah melalui Dinas Pendidikan Nasional terkait dengan gerakan gemar membaca maka setiap satuan pendidikan di Sekolah Menengah Pertama wajib memiliki perpustakaan sekolah. Pemerintah sudah berupaya menganggarkan dana ke setiap sekolah khususnya sekolah negeri untuk pengadaan ruang perpustakaan. Hal ini dilakukan sebagai upaya memberikan motovasi kepada seluruh warga di satuan pendidikan agar perpustakaan sekolah menjadi tempat yang ideal untuk memenuhi keperluan bagi setiap warga sekolah mendapatkan sumber - sumber informasi yang diperlukan, sekaligus sebagai sarana untuk menambah wawasan dan tempat untuk menyalurkan kesenangan membaca. Perpustakaan sekolah yang baik harus sesuai dengan ketentuan yang sudah berlaku secara internasional baik bangunan secara fisik, sistematis pengelolaannya, dan pengelolanya (pustakawan) yang sudah memahami bagaimana cara mengelola perpustakaan sekolah yang ideal. Melalui sebuah perpustakaan sekolah yang baik dan sudah memenuhi standar tentu saja diharapkan dapat memberikan dampak positif dalam rangka meningkatkan minat membaca dikalangan peserta didik dan Gerakan Literasi Sekolah yang menjadi pogram pemerintah dapat diimplementasikan secara maksimal dan berkelanjutan, dan menjadi harapan kita bahwa budaya membaca di Indonesia tidak hanya terjadi di lingkungan sekolah tapi juga di dalam keluarga, masyarakat, tempat - tempat ruang publik, kantor - kantor pemerintahan dan dimana saja, karena dengan membaca bisa membuka wawasan berpikir seseorang, menambah ilmu pengetahuan dan tahu dengan yang terjadi disekelilingnya. Dengan membaca juga dapat memberikan dampak yang positif bagi perkembangan psikologi anak, menanamkan nilai - nilai karakter, membentuk kepribadian anak, dan memiliki rasa percaya diri.

Saat ini sekolah sebagai salah satu cara untuk menumbuhkan budi pekerti siswa sekolah dalam bentuk Gerakan Literasi Sekolah. GLS sudah dirancangkan secara masih disemua jenjang sekolah mulai SMP sampai dengan SLTA melalui gerakan membaca buku 15 menit sebelum pembelajaran dimulai. Gerakan ini dilakukan emlalui penciptaan ekeosistem sekolah sekolah yang mampu mendorong kebiasaan siswa untuk memanfatakan infromasi. GLS diharapkan akan mampu membentuk siswa menjadi insan pembelajar sepanjang hayat. Ada tiga hal yang mendasari perlunya keberaksaraan informasi. Pertama, secara umum adalah adanya kebutuhan peningkatan kemampuan belajar secara terusmenerus dan berkelanjutan serta mandiri, agar seseorang dapat hidup sukses dalam masyarakat informasi. Kedua, secara khusus, adalah agar dalam penerapan kurikulum di sekolah dapat berjalan dengan baik dibutuhkan dukungan berbagai sumber belajar bagi peserta didik dari berbagai format dan jenis sumber belajar yang tersedia. Ketiga, untuk membiasakan, melatih, mengkondisikan peserta didik melalui ekosistem sekolah yang kondusif agar nantinya dapat menjadi manusia pembelajar sepanjang hayat.

Karakter gemar membaca adalah kebiasaan menyediakan waktu untuk membaca berbagai bacaan yang memberikan kebajikan bagi dirinya. karakter menghargai prestasi adalah karakter yang terwujud dalam bentuk sikap dan tindakan yang mendorong dirinya untuk menghasilkan sesuatu yang berguna bagi masyarakat, dan mengakui, serta menghormati keberhasilan orang lain. Karakter yang bersahabat atau komunikatif maksudnya adalah suatu sikap dan tindakan yang mendorong dirinya untuk menghasilkan sesuatu yang berguna bagi masyarakat, dan mengakui, serta menghormati keberhasilan orang lain. Sumber daya manusia yang terlibat untuk mendukung kebijakan Gerakan Literasi Sekolah ini adalah seluruh warga sekolah baik kepala sekolah, guru, karyawan, siswa, dan orangtua siswa. Pendidikan karakter melalui Gerakan Literasi Sekolah tidak menjadi trend manakala hanya dijadikan komoditi, promosi dalam dunia pendidikan. Pendidikan karakter selalu berproses dan tidak pernah selesai dilakukan oleh individu. Proses itu terus menerus dilakukan untuk penyempurnaan. 
Upaya yang diterapkan oleh pihak sekolah dalam menghadapi hambatan peran kegiatan literasi dalam meningkatkan minat membaca dan menulis siswa kelas atas yakni dengan memberi sosialisasi ketika upacara supaya anak seringsering mengunjungi perpustakaan untuk membaca dan menulis dan secara berkala mendiskusikan upaya atau metode yang tepat untuk diterapkan dalam pelaksanaan kegiatan literasi agar minat membaca dan menulis siswa meningkat. Tidak hanya berhenti disitu saja upaya yang diterapkan oleh pihak sekolah di dalam menghadapi hambatan dalam implementasi kegiatan literasi untuk meningkatkan minat membaca dan menulis siswa kelas atas, pihak sekolah membuat jadwal masuk perpustakaan per kelas bekerjasama dengan perpustakaan keliling dari kabupaten serta mengadakan lomba-lomba untuk mendorong siswa lebih berpartisipasi aktif dalam membaca dan menulis. Dari uraian di atas dapat diketahui bahwa temuan dari penelitian ini yakni kegiatan literasi memiliki peran dalam meningkatkan minat membaca dan menulis peserta didik. Kegiatan ini pula yang membuat siswa mulai tertarik untuk mengikuti berbagai lomba-lomba yang diadakan oleh pihak sekolah maupun pihak luar dengan penuh rasa tanggung jawab.

\section{SIMPULAN DAN SARAN Simpulan}

Berdasarkan analisis data dari hasil penelitian yang telah peneliti paparkan di atas, maka peneliti dapat memberikan kesimpulan sebagai berikut: (1) Kegiatan pelaksanaan gerakan literasi sekolah yang dilaksanakan oleh sekolah menengah pertama (SMP) dalam mengembangkan keperpustakaan telah dilakukan dan diterapkan untuk menumbuhkan minat baca peserta didik serta dapat menambah wawasan pengetahuan yang luas; (2) Dengan adanya gerakan literasi sekolah dapat menghasil kan perubahan karakter peserta didik terutama dalam kemajuan berkunjungnya keperpus-takaan dan meningkatnya minat baca peserta didik sehingga dapat menambah pengetahuan yang luas.

\section{Saran}

Adapun saran yang peneliti dapat berikan berdasarkan hasil penelitian yang telah dilakukan ialah: (1) Untuk mendukung dan mensukseskan Gerakan Literasi di Sekolah, disarankan agar di setiap satuan pendidikan tingkat Sekolah Menengah Pertama memiliki perpustakaan sekolah; (2) Para guru disetiap satuan pendidikan perlu melakukan sosialisasi kepada peserta didik sehingga mereka rajin berkunjung dan mencintai perpustakaan sebagai sarana untuk mendapatkan informasi, sebagai media pendidikan dan sebagai tempat untuk menyalurkan kegemaran membaca bagi peserta didik, (3) Perpustakaan sekolah yang baik harus dikelola dengan baik sesuai ketentuan yang sudah berlaku secara Internasional; baik itu bangunannya secara fisik, tata kelola penempatan bahan-bahan pustaka, koleksi pustaka, maupun pustakawannya, dan Tradisi mengunjungi perpustakaan dan belajar mandiri harus selalu ditanamkan kepada siswa Sekolah Menengah Pertama, tidak hanya lisan, namun dengan langkah - langkah yang konkrit dan keteladanan para guru. Dengan demikian diharapkan para siswa Sekolah Menengah Pertama dapat menjadi generasi yang mampu mewujudkan masyarakat gemar membaca yang sesunguhnya.

\section{DAFTAR RUJUKAN}

Annisa, I.N., 2017. Implementasi Gerakan Literasi Sekolah (Gls) Di Sekolah Dasar (Doctoral dissertation. Universitas Muhammadiyah Purwokerto.

Bafadal Ibrahim, 2008. Pengelolaan Perpustakaan Sekolah. PT Bumi Aksara : Jakarta.

Buchori, Mochtar. 1995. Transformasi Pendidikan. Jakarta: IKIP Muhammadiyah Jakarta Press.

Dalman. 2013. Keterampilan Membaca. Jakarta: rajawali Pers.

Dirjen Dikdasmen. 2016. Panduan Gerakan Literasi di Sekolah Menengah Atas. Jakarta: Direktorat Jenderal Pendidikan Dasar Dan Menengah Kementerian Pendidikan Dan Kebudayaan

Farr, R. 1984. Reading: Trends an Challenges. Washington D. C.: National Education Association.

Soeatminah, 1992. Perpustkaan Kepustakawanan dan Perpustakawan. Kanisius Yogyakarta.

Wulandari, R., 2017. Implementasi Kebijakan Gerakan Literasi Sekolah Di Sekolah Dasar Islam Terpadu Lukman Al Hakim International (Doctoral dissertation, Fakultas Ilmu Pendidikan). 